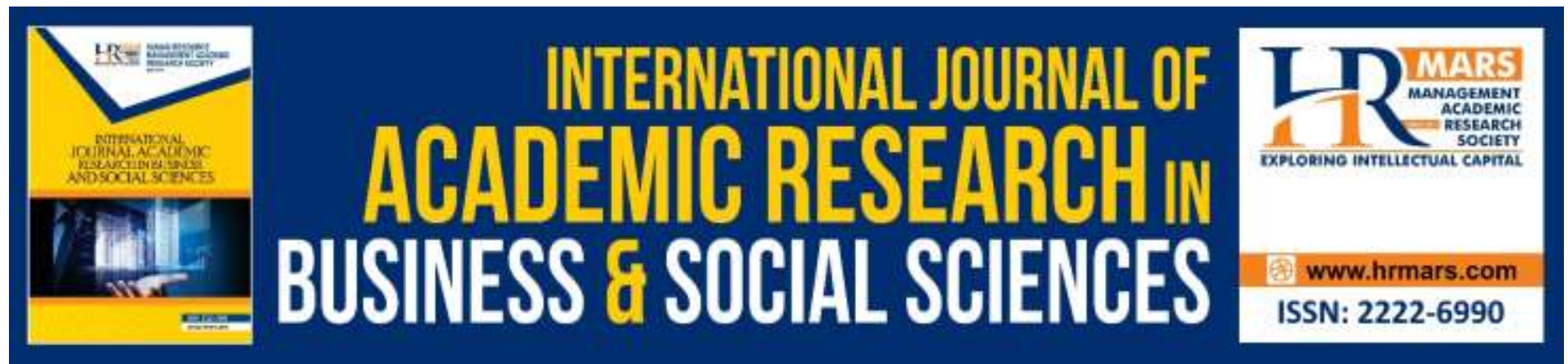

\title{
The Comprehensive Aspect in Islam from Quran and Hadith Perspective
}

Norsyahira Cik Hamid, Wan Khairul Aiman Wan Mokhtar

To Link this Article: http://dx.doi.org/10.6007/IJARBSS/v9-i11/6575

DOI: 10.6007/IJARBSS/v9-i11/6575

Received: 01 October 2019, Revised: 24 October 2019, Accepted: 08 November 2019

Published Online: 30 November 2019

In-Text Citation: (Hamid \& Mokhtar, 2019)

To Cite this Article: Hamid, N. C., Mokhtar, W. K. A. W. (2019). The Comprehensive Aspect in Islam from Quran and Hadith Perspective. International Journal of Academic Research in Business and Social Sciences, 9(11), 557-564.

Copyright: (C) 2019 The Author(s)

Published by Human Resource Management Academic Research Society (www.hrmars.com)

This article is published under the Creative Commons Attribution (CC BY 4.0) license. Anyone may reproduce, distribute, translate and create derivative works of this article (for both commercial and non-commercial purposes), subject to full attribution to the original publication and authors. The full terms of this license may be seen

at: http://creativecommons.org/licences/by/4.0/legalcode

Vol. 9, No. 11, 2019, Pg. 557 - 564

http://hrmars.com/index.php/pages/detail/IJARBSS

JOURNAL HOMEPAGE

Full Terms \& Conditions of access and use can be found at http://hrmars.com/index.php/pages/detail/publication-ethics 


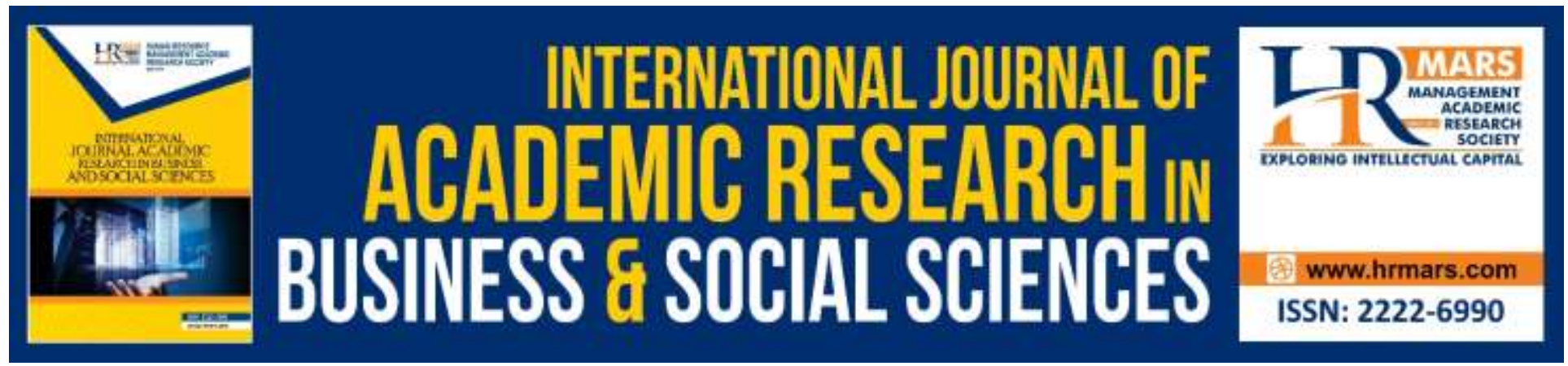

\title{
The Comprehensive Aspect in Islam from Quran and Hadith Perspective
}

\author{
Norsyahira Cik Hamid, Wan Khairul Aiman Wan Mokhtar \\ Universiti Sultan Zainal Abidin (UniSZA), Kampus Gong Badak, 21300 Kuala Nerus, Terengganu, \\ Malaysia
}

\begin{abstract}
This study aims to analyse and identify about Islam is a comprehensive religion that covers all era and all events have occurred on the face of the earth and human's life. By using the title of Islam is a comprehensive religion is one of the best approaches to collect, identify, classify and analyse the verses of the Al-Quran relating to the identified topic of discussion. With the method of Conventional Research Methodology (CRM), techniques used to identify, analyse and collect data according to the sources of Islamic journals and articles from the internet. The question arises about this situation are; what are kind of brochures existed in Islam? Is it true Islam is suitable for all human? What makes Islam is the best religion to adopt? To answer these questions, this study has three objectives. First, purposefully done to recognize the concept of Islam is a comprehensive religion. Secondly to study and analyse that Islam has too many brochures to show it comprehensively. Finally, to tell that Islam teaches us to become a perfect Muslim so Islam can be adopted to all. This qualitative study uses content analysis for the purpose of analyzing data collected. Through this approach, considered the most appropriate to implement the concept of Islam is a comprehensive religion for two reasons. First, the description of Islam is a comprehensive religion by learning the pronunciation and the second, about the study of Hadith and certain verses from Al-Quran. The first method of Islam is a comprehensive religion that confirms the main source of Islam are Hadith and Al-Quran. Second, this method appears to be the most appropriate way to collect, identify, classify and analyse data for the purpose of meeting the needs of today's society.
\end{abstract}

Keywords: Comprehensive, Religion, Islam

\section{Introduction}

In pursuing this tide of modernization, there are various religions professed by all residents on the face of the Earth God. Religion is the most best is Islam. There are various aspects that distinguish Islam with other religions. Among the aspects it different was in terms of ideology or 
philosophy known human is comprehensive or all of that includes every single thing. Islam covers all era and covers the whole event has occurred on the face of the earth and human life (alQaradhawi, n.d.).

The questions are, what are kind of brochures existed in Islam? Is it true Islam is suitable for all human? What makes Islam is the best religion to adopt?

Discussion on collecting and analyzing data based on hadith is very important to carry out. Therefore, it is more important to identify the best method that can be used in realizing the technique mentioned above. Hence, this study was conducted for both purposes; first to identify the concept of Islam is comprehensive religion and the second objective is to show that Islam is the best religion to adapt.

In general, the research papers are divided into two main categories. The first part is the discussion of Islam is a comprehensive religion. Secondly, analytic discussion of the brochures exits in Islam. The last one is Islam is the best religion to adopt by everyone in the world because it is comprehensive.

\section{Research Methodology}

To produce a study in a proper way, research methodology must be applied. Researchers must planned and applying a right methodology to produce a right findings. (Mokhtar, 2017) To achieve the goal of this study, qualitative research has been used. This study focuses on descriptive research. In addition, the data used through internet research as a data collection tool. Data were analysed using content analysis method. From the data analysis, a conclusion was made. (Mokhtar, 2017; Jusoh \& Mlibari, 2018).

\section{Findings and Research Discussion}

For the purpose of discussing the concept of Islam is a comprehensive religion. Secondly, the concept of Islam has too many brochures and finally the discussion of Islam is the best religion for all.

\section{Definition of Islam is a Comprehensive Religion}

In pursuing this tide of modernization, there are various religions professed by all residents on the face of the Earth God. Religion is the most best is Islam. There are various aspects that distinguish Islam with other religions. Among the aspects it different was in terms of ideology or philosophy known human is comprehensive or all of that includes every single thing. Islam covers all era and covers the whole event has occurred on the face of the earth and human life (Dr Yusuf al-Qaradhawi, n.d.). A scholar reflects that the breadth of meaning of the comprehensive in the brochure of Islam are as follows:

"Islam is the leaflet length covers all era, its width arrange all aspects of human life and in it covers every question the world and also the hereafter".

Islam is a comprehensive religion and everything contained in it does not mean it is not activated by the admiration of it is adherents. Islamic appreciation means to carry out in the form of Islamic teaching practices with all the scope available comprehensively and it must be rooted in 
knowledge, understanding and practice ( Mansor, 2016). The fundamental principles of Islamic appreciation include the three principles of the creed as the core in Islam and the life of believers (Ibn-Mukarram, 1994).

\section{Islam is Brochure of All Time}

Islam is brochure for all era and generations, not a limited brochure at a certain time whose role is depleted at the end of time, as is the condition of previous Prophets S.A.W. Every Prophet has been sent for a certain period. When that period is expired, then Allah S.W.T. send another prophet. The Prophet Muhammad S.A.W. is the closing of the prophets. Therefore, the brochure is a lasting brochure that goes on until the Qiamat day and covers the whole of nature. This brochure brings the last guide to man. It is clear that there is not syariat after Islam, no book after the Quran and no Prophet after Prophet Muhammad S.A.W.

There is no doubt that Islam is perpetual future brochure and a distant past. However, the principle of iqtikad and it is moral is a brochure on every prophet sent and every book passed down. So, all the prophets came with Islam, calling Tauhid and away from Thaghut. (alQaradhawi, 1995).

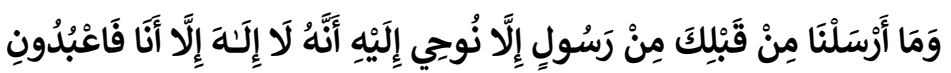

Translation: "And we did not send a Messenger before you, but we revealed to him: There is no god except me, then worship Me."

(QS al-Anbiya': 25). Indeed Islam is the essence of the brochure of every Prophet who comes and s.w.t God's side. Since and greeted Prophet Nuh Alaihis' to Prophet Muhammad S.A.W. Islam is a brochure of all time.

\section{Islamic Brochures for Education}

According to Ibrahim et al. (2013), the followers of liberal Islam have a variety of beliefs etymologically, education comes from words that get prefixes and endings- meaning processes, actions, ways to educate, preserve and teach. Educational terms translated into English with education which means development or guidance. In Arabic this term is often translated with tarbiyah which means education (Tim Penyusun Kamus Pusat, Kamus Besar Bahasa Indonesia). In the context of Islam, the term education is sometimes used with the word tarbiyah, ta'lim and ta;dib. Tarbiyah with the basic word "rabba" which means educating, rearing, nurturing, developing and growing (Mahmud Yunus, 1990). The word tarbiyah in particular in Al-Quran refers to the child and related to the mandatory effort, and is burden of adults especially parents towards their children (Hassan Muhammad Hassan dan nadiyah Jamaluddin, 1999). In addition to the word tarbiyah, in the context of Islam, educational terms are sometimes used word ta'lim with the basic word 'Allama which means teaching. Like the word of Allah S.W.T in Quran Surah Al- Baqarah verse 31 which reads:

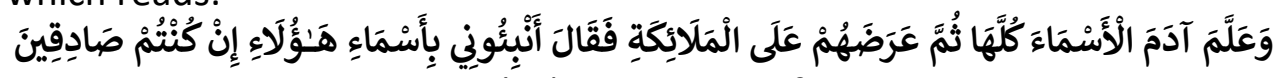

Translation: "And He teaches to Adam the name (all) things, then forward it to the angels and say: "Speak to Me the names of those things if you are the truthful." 
(QS Al-Baqarah : 31).

Ta'lim is a continuous learning process that has occurred since the human being was born through the development of several functions of hearing, sight and heart. And that development is an adult's responsibility when a child is young, but after they grow up, people should learn independently until they cannot continue teach (Ali, 1999; Anastasiadou \& Griva, 2018) Anastasiadou \& Griva, 2018) Anastasiadou \& Griva, 2018; Anastasiadou \& Griva, 2018).

Word of education (tarbiyah) and teaching (ta'lim) have different meanings. According to Mahmud Yunus, educating means preparing children with all kinds of ways in order to utilize their energy and talents as best they can to achieve a perfect life in society. While teaching means transferring knowledge to the child so that he is clever. From that understanding it can be understood that educating has broader and deeper coverage than teaching, as Mahmud Yunus reveals that teaching is one of the facets of some aspects of education. In teaching, educators gives students the knowledge, opinions, and thoughts according to the methods he or she likes. Educators talk, learners listen: active educators, passive learners. While in educating, educators give learners should retaliate, investigate, and think about difficult problems, looking for ways to overcome such difficulties (Pendidikan Islam: Tradisi dan Modernisasi).

In addition to the word tarbiyah and ta'lim, the term education in the Islamic context is also used ta'dib, means education related to behaviour or morality in a life that is more in reference to the improvement of human dignity (Nata, 2005).

\section{Law Criteria According to Islamic Brochure}

Islamic law is one of the six major legal systems in the world. The six legal systems are: 1) Islamic law, namely the characteristics and the Approach of the Islamic Aspects of Islamic Law Muddasir, Edi Gunawan the law based on the Al-Quran, Al-Sunnah and ljtihad mujtahid; 2) Civil (Roman) Law, namely the civil code of codified civil code. This legal system is rooted in law. The Roman law is practiced by continental and some European countries its former colonies; 3) Common law, which is law based on custom or habits, precedents or judge made law. This legal system practiced in Anglo Saxon countries, such as England and America; 4) Socialist law, the legal system practiced in communist countries; 5) Sub-Saharan Africa, the legal system practiced in the African countries in the south Sahara desert; and 6) Far east, a complex legal system that embodies unity between civil law systems, common law and Islamic law as the fundamental basis of society (Suherman, 2006: 21-23; Isynuwardhana, Surur, 2018).

Islamic law includes various dimensions, abstract dimensions, in all forms the commandments and prohibitions of Allah and His Messenger, and the concrete dimensions, in the form of a behavior a constant among Muslims as an effort to execute the command of God and His apostle. More concrete again, in the form of human behavior, both individually or collective. Islamic law also includes substantial internalization various social institutions (Bisri, 2004: 31).

Islamic law has its own character, which has no commonality or in contrast to the characteristics of other applicable law systems in the world. That difference because Islamic law comes from Allah S.W.T. which is not artificial human and independent of individual and group interests and 
free from air lust. One example of the characteristics of Islamic law is to minimize the burden and not burdens the law which is revealed by Allah S.W.T can be implemented by humans so that the goal of syariah can be achieved and human beings can achieve happiness in the world and in the hereafter.

Islamic law experts have discussed a lot about the characteristics of Islamic law this with different literature. However, in discussing these characteristics they agree to guide Quran Surah Al-A'raf: 157:

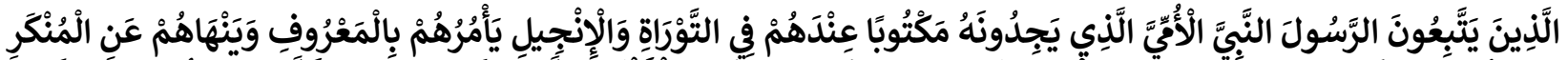

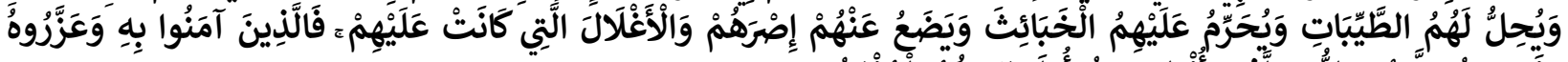

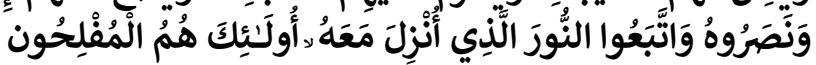

Translation: "Those who follow the Messenger, the Prophet of the Believers who they find written in the Torah and the gospel which is by their side, which hath sent them do the ma'ruf and forbid them from doing wrong and justify them all good and forbid them all and throw away from them the burdens and the fetters that are in them. So those who believe in it. Glorify him, help him and following the light which is revealed to him (Al-Qur'an), they are the lucky ones."

(QS Al-A'raf : 157)

The verse explains that the original man had no bounds for behave, then Allah limits the human being to behave well in order directed in worship and behave. In order for human beings to carry out the behavior well, Allah gives ease and ease to what has been commanded

by Allah can be exercised as it should (Manan, 2006: 95). Every human beings have the virtues of kindness, then humans have to be able to behave as they are his nature, that is to do well. In acting and behaving, man certainly limited by the rules that Allah has revealed, so that humans do not acting beyond the limits of syariah.

\section{Islam is a Human's Brochure}

Islam is a brochure to humans, which is taken from the point of human beings as a whole. It is not a brochure for common sense without the spirit, not also spiritual without physical, not mind without feeling and not vice versa. It is human full brochure that is spirit, intellect, free will and feelings.

Indeed, Islam does not divine mankind into two parts as had been done by other religions. The first part spiritual conducted by religious and directs to the place of worship. The division became the privilege of religious groups and free games for ecclesiastics and the wizard for direct human and others. While the second part consists of things, that there is no authority for religion and religious groups to it, but there is no field for God on it. The division became a field for life, the world, politics, society and the nation. It is the largest division in human life.

But what is this situation compatible with human nature and habits according to what have been created by God? No, never! Man as created by God is not divided and unable to be separated. It is mankind. Then, its purpose must be one. This is done by Islam, which makes the goal of God and toward it hereafter.

With this, human will not be split into two different directions or two opposite power. The one to the East and another to the West. It is just like a servant belonging to some of owners, every 
person giving orders to the contrast by others, then the servant becomes more uncertain direction, his mind messy, his heart was a mess (al-Qaradhawi, 1995), as described by Allah in the Quran:

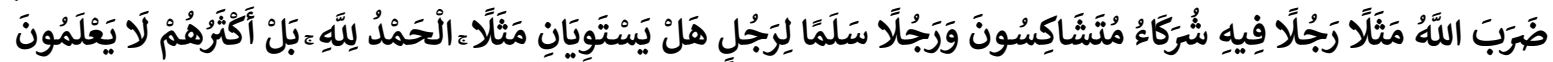
Translation: "Allah makes a parable of a man (a slave belonging to a number of people who are in a state of affiliation and a slave who is full of property and a man (alone), whether the two slaves are the same."

(QS Az-Zumar: 29)

\section{Conclusion}

In a nutshell, In my opinion, following and emulating the system of life in Islam is very important for every human being as it can be used in our lives. In addition, through this system, human beings can carry out their daily activities according to the demands or correctness of the Islamic syariah as Islam is a complete religion of every aspect of life beyond the other religions and gives the benefit to mankind itself (Baim, 2013).

\section{Acknowledgement}

This paper is founded on the research project of the Fundamental Research Grant Scheme FRGS/1/2018/SSI03/UNISZA/02/2 (Project No: RR279). Special appreciation is owed to Ministry of Higher Education Malaysia (MOHE) and Universiti Sultan Zainal Abidin (UniSZA) for sponsoring and supporting this research.

\section{Corresponding Author}

Wan Khairul Aiman bin Wan Mokhtar (Ph.D), Senior Lecturer, Universiti Sultan Zainal Abidin (UniSZA), Kampus Gong Badak, 21300 Kuala Nerus.

Email: wk_aiman@yahoo.com / wkhairulaiman@unisza.edu.my

\section{References}

Al-'Ainain, A.K. (1980). Falsafah at-Tarbiyah al-Islamiyyah fi al-Qur'an al-Karim. Egypt: Dar al-Fikr al-Arabiyyah.

al-Attas, S. M. N. (1996). Concept of Islamic Education. A Framework for the Construction of the Philosophy of Islamic Education. (Haidar Bagir, trans.) Bandung: Mizan, 1996.

Anastasiadou, A., \& Griva, E. (2018). Identifying Teachers' Views on the Impact of Early Foreign Language Learning on Children's Linguistic Development. 2Multilingual Academic Journal of Education and Social Sciences, 6(1), 21-40.

Basri, A. (1984). Islamic Education as the Movement of Islamic Reform. Bandung: al-Ma'arif. Bisri, H. C. (2004). Islamic Law Research Pillars and Social Provisions. Jakarta: Rajawali Pers. Deannes Isynuwardhana, D., Surur, G.N.I. (2018). Return Analysis on Contract Option Using Long Straddle Strategy and Short Straddle Strategy with Black Scholes, International Journal of Academic Research in Accounting, Finance and Management Sciences 8 (4): 16-20. 
Great Dictionary of Bahasa Indonesia. (n.d.). Team of Dictionaries Center Dictionary. h. 204;

Hassan, H. M. \& Jamaluddin, N. (1984). Madarisat-Tarbiyah fi al-Hadarah al-Islamiyah. Cairo: Dar al-Fikr al-Arabi.

Ibn-Manzur \& Ibn-Mukarram. (1994). Lisan al-'Arab. Vol. 3. Beirut: Dar al-Sadir.

Jusoh, R., \& Mlibari, N. A. R. M. (2018). Predictors of Quality Teaching in Makkah Primary Schools. International Journal of Academic Research in Progressive Education and Development, 7(4), 30-50

Maksum, H. (1999). Madrasah: Sejarah dan Perkembangannya. Jakarta: Logos Wacana Ilmu. Maman, S. A. (2006). Introduction to Legal System Comparisons. Cet. 2. Jakarta: Rajawali Pers.

Mokhtar, W. K. A. W. (2017). Concept Al-Hadīth Al-Mawḍū'iy as A Method of Collecting and Analyzing Research's Data. International Journal of Academic Research in Business and Social Sciences, 7(2), 536-542.

Nata, A. (2005). Islamic Education Philosophy. Jakarta: Primary Young Style.

Qardhawi, M. Y. (1983). Islam Dakwah Yang Syumul. Kuala Lumpur: ABIM.

Yunus, M. (1990). Arabic-Indonesian Dictionary. Cet. 3. Jakarta: Hidakarya Agung. 